\title{
Effects of replacing wheat starch with glycerol on methane emissions, milk production, and feed efficiency in dairy cows fed grass silage-based diets
}

\author{
Johanna Karlsson, ${ }^{1 *}$ Mohammad Ramin, ${ }^{2}$ Marko Kass, ${ }^{2,3}$ Mikaela Lindberg, ${ }^{1}$ and Kjell Holtenius ${ }^{1}$ \\ ${ }^{1}$ Department of Animal Nutrition and Management, Swedish University of Agricultural Sciences, SE-75323, Uppsala, Sweden \\ ${ }^{2}$ Department of Agricultural Research for Northern Sweden, Swedish University of Agricultural Sciences, SE-901 83, Umeå, Sweden \\ ${ }^{3}$ Department of Animal Nutrition, Estonian University of Life Sciences, 51006, Tartu, Estonia
}

\section{ABSTRACT}

To lower the effect of climate change from cattle production, we should aim at decreasing their enteric methane emissions per kilogram of milk or meat. Glycerol may be absorbed through the rumen epithelium and would consequently be less available to microbes in the rumen. Glycerol could thus supply dairy cows with energy for milk production without contributing much to methane production. This study evaluated the effect of replacing wheat starch with glycerol on milk production, feed intake, and methane emissions. Twentytwo Swedish Red cows in mid lactation were used in a switch-back, change-over experiment with 3 periods of $21 \mathrm{~d}$. The 2 dietary treatments consisted of a total mixed ration based on $(\mathrm{g} / \mathrm{kg}$ of dry matter) grass silage (605), rapeseed meal (120), and barley (70) and either wheat starch or refined glycerol (200) fed ad libitum. The glycerol diet resulted in higher dry matter intake (21.6 vs. $20.1 \mathrm{~kg} / \mathrm{d}$ ) and methane emissions (482 vs. 423 $\mathrm{g} / \mathrm{d}$ ) compared with the diet containing wheat starch, whereas no difference was found in energy-corrected milk yield (28.4 vs. $29.7 \mathrm{~kg} / \mathrm{d}$ ). These results indicate that when glycerol is mixed with the feed, it is available to rumen microbes to a larger extent than initially assumed. Compared with wheat starch, adding refined glycerol $(200 \mathrm{~g} / \mathrm{kg}$ of dry matter) to the feed of dairy cows does not seem to have the potential to decrease enteric methane emissions.

Key words: starch, glycerin, milk composition, greenhouse gas

\section{INTRODUCTION}

Livestock production is responsible for approximately $29 \%$ of the world's anthropogenic methane $\left(\mathrm{CH}_{4}\right)$ emissions (US EPA, 2013), which contribute to global

Received August 31, 2018.

Accepted April 30, 2019.

*Corresponding author: johanna.karlsson@slu.se warming. Future feeding and management systems for dairy cows should aim to decrease $\mathrm{CH}_{4}$ emissions per kilogram of milk or meat, thus diminishing their effect on the environment (Ramin and Huhtanen, 2013). Highstarch diets have been shown to decrease $\mathrm{CH}_{4}$ emissions in ruminants (Hristov et al., 2013). Starch degradation generally increases production of propionate (Sutton et al., 2003; Agle et al., 2010).

Werner Omazic et al. (2015) showed that glycerol is absorbed across the rumen epithelium in significant amounts and would presumably be less available for fermentation in the rumen. Thus, it could have the potential to provide ruminants with energy without contributing much to $\mathrm{CH}_{4}$ production in the rumen. Any glycerol that is not absorbed across the rumen epithelium increases propionate, butyrate, and valerate concentrations in the rumen while decreasing acetate (Ariko et al., 2015; Castagnino et al., 2018). When the acetate:propionate ratio decreases, $\mathrm{CH}_{4}$ production also decreases (Russell, 1998). Thus, both starch and glycerol are considered to have potential in reducing enteric $\mathrm{CH}_{4}$ emissions because they decrease the acetate: propionate ratio.

There have been a few studies on the effects of adding dietary glycerol (around $200 \mathrm{~g} / \mathrm{kg}$ of diet DM or more) to dairy cattle rations. Donkin et al. (2009) supplemented maize-based diets with up to $150 \mathrm{~g} / \mathrm{kg}$ DM of refined glycerol for lactating dairy cattle without negative effects on milk production. However, feeding diets in which maize was replaced with crude glycerol at a level of $300 \mathrm{~g} / \mathrm{kg}$ of dietary DM had adverse effects on lactation performance (Ezequiel et al., 2015).

Current evidence on the influence of glycerol on DMI in dairy cows is conflicting. Kass et al. (2012) observed higher DMI but reduced feed efficiency when barley meal was replaced with glycerol in the dairy cow diet. Other studies have reported no effect of glycerol administration (Donkin et al., 2009; Boyd et al., 2011) or adverse effects on DMI (Ezequiel et al., 2015). However, those studies were unable to discriminate effects of variations in NDF intake and rumen fill from effects of glycerol on DMI. It has been shown that glycerol in- 
duces a reduction in forage DM digestibility compared with maize in vitro (Benedeti et al., 2018). However, only a few studies have estimated the energy value of glycerol for lactating dairy cows. Therefore, Donkin (2008) recommends that glycerol can be assumed to contain amounts of energy similar to the amounts in maize starch.

Moreover, previous experiments demonstrating how $\mathrm{CH}_{4}$ production is affected by glycerol have mainly been conducted in vitro. The results are conflicting, varying from no effect (Avila et al., 2011; Castagnino et al., 2015) to an increase (Avila-Stagno et al., 2014; Danielsson et al., 2014) or a decrease (Lee et al., 2011) in $\mathrm{CH}_{4}$ production. Results from in vitro experiments give some indications on the effect of diet on $\mathrm{CH}_{4}$ emissions but should be followed up with in vivo studies to include effects of the whole animal or herd (McAllister et al., 2011).

The objective of the present study was to investigate whether $\mathrm{CH}_{4}$ emissions are reduced when starch is replaced with glycerol in dairy cows fed a grass silagebased diet. An additional objective was to investigate whether feed intake, lactation performance, and OM digestibility are affected when the diet is supplemented with glycerol instead of starch.

\section{MATERIALS AND METHODS}

The study was performed at the Department of Agricultural Research for Northern Sweden, the Swedish University of Agricultural Sciences, Umeå $\left(63^{\circ} 45^{\prime} \mathrm{N}\right.$, $20^{\circ} 17^{\prime} \mathrm{E}$ ), between February and April 2016. The study was approved by the Umeå Ethics Committee for Animal Research, Umeå, Sweden (diary no. A72/15), and the experiment was carried out in accordance with the laws and regulations controlling experiments performed with live animals in Sweden.

\section{Animals, Experimental Design, and Diets}

Twenty-two Swedish Red dairy cows (104 \pm 22 DIM, $25.4 \pm 5.3 \mathrm{~kg}$ of milk; mean $\pm \mathrm{SD}$ at start of study), both multiparous and primiparous, were housed in an insulated loose-housing barn with rubber mat and sawdust-bedded cubicles. The cows were milked twice a day, starting at 0600 and $1500 \mathrm{~h}$, in a milking parlor (SAC, S.A. Christensen and Co. Ltd., Kolding, Denmark). The cows were blocked into 3 blocks: (1) primiparous cows with low yield $(\mathrm{n}=8),(2)$ multiparous cows with low yield $(\mathrm{n}=6)$, and (3) multiparous cows with high yield $(\mathrm{n}=8)$. Low milk yield was defined as $<32 \mathrm{~kg} / \mathrm{d}$, and high yield was defined as $>32 \mathrm{~kg} / \mathrm{d}$. There were no primiparous cows with high milk yield. The purpose of the blocking was to keep cows within each block as similar as possible. Within each block, an equal number of cows were randomly assigned to the 2 treatment sequences, $\mathrm{ABA}$ and $\mathrm{BAB}$. A switch-back, change-over design was used, with 2 diets as treatments and 3 periods of $21 \mathrm{~d}$ each. The first $14 \mathrm{~d}$ of each period were used for adaptation, whereas sampling and data collection were performed during the last $7 \mathrm{~d}$.

The cows were fed a TMR ad libitum in roughage intake control feeders (Insentec B.V., Marknesse, the Netherlands). Each animal had access to the same 6 feeders during the whole study. A stationary feed mixer and automatic feed wagons (Nolan A/S, Viborg, Denmark) were used to distribute fresh feed to the cows 4 times/d, and the amounts were adjusted to ensure up to $10 \%$ feed refusal. Dietary treatments consisted of a control with wheat starch (STA) at $200 \mathrm{~g} / \mathrm{kg}$ of DM and a treatment diet with refined glycerol (GLY) at $200 \mathrm{~g} / \mathrm{kg}$ of DM (Table 1). Apart from glycerol and starch, both diets contained $(\mathrm{g} / \mathrm{kg}$ of $\mathrm{DM})$ grass silage (605), crimpled barley (70), rapeseed meal (120), and a mineral mix (5). The diets were estimated to be isofiberous, isonitogenous, and roughly isoenergetic, although the tabulated energy levels available for wheat starch (8.2 MJ of $\mathrm{NE}_{\mathrm{L}} / \mathrm{kg}$ of $\mathrm{DM}$; value for maize starch) were somewhat higher than for pure glycerol (7.5 MJ of $\mathrm{NE}_{\mathrm{L}} /$ $\mathrm{kg}$ of DM; NorFor, 2018). During a 2-wk preadjustment period, all cows were fed a diet with glycerol and wheat starch, each at a level of $100 \mathrm{~g} / \mathrm{kg}$ on a DM basis, to adapt the rumen microbes to both wheat starch and glycerol before the experimental treatment periods.

The silage was first-cut, precision-chopped material from a 2-yr perennial grass sward sown with $80 \%$ timothy (Phleum pratense L.) and 20\% red clover (Trifolium pratense L.). Experimental silage was stored in a bunker silo and preserved using an acid-based additive (Promyr NT 570, Perstorp, Sweden) provided at 3.5 to 4.0 $\mathrm{L} / \mathrm{t}$. The crimped barley was rolled, preserved with 3.5 $\mathrm{L} / \mathrm{t}$ of propionic acid, and stored in airtight bags. The rapeseed meal was solvent extracted and heat-moisture treated with low levels of glucosinolates and erucic acid (ExPro, AAK Sweden AB, Karlshamn, Sweden). The wheat starch was a food-grade, fine-grained powder (Foodstar, Kröner-Stärke, Ibbenbüren, Germany) distributed into the feed mixer by mineral feed dispensers. The refined glycerol was of technical grade (99.5\%, AAK Sweden AB). It was mixed with $33 \%$ drinking water to lower the freezing point and pumped into the feed mixer. The mineral mix contained $(\mathrm{g} / \mathrm{kg})$ ash (985), Ca (153), P (9), Mg (120), K (1.9), Na (85), and S (8.0; Effekt Intensiv, Lantmännen Lantbruk, Malmö, Sweden). In addition, the cows were given on average $1.4 \mathrm{~kg} / \mathrm{d}$ of a pelleted concentrate mixture (Komplett Fiber 170, Lantmännen Lantbruk) that contained (per $\mathrm{kg}$ of $\mathrm{DM}$ ) 7.1 MJ of $\mathrm{NE}_{\mathrm{L}}, 170 \mathrm{~g}$ of $\mathrm{CP}, 270 \mathrm{~g}$ of $\mathrm{NDF}$, 
and $296 \mathrm{~g}$ of starch to encourage them to visit a gas measurement system.

\section{Measurements and Sample Collection}

The cows were weighed before the start of the trial and subsequently after morning milking on d 19 to d 21 in each experimental period. The mean BW $( \pm \mathrm{SD})$ for all cows just before the start of the experiment was $574 \pm 79 \mathrm{~kg}$. The BCS was recorded simultaneously by 2 trained individuals before the experiment and at the end of each period using the system proposed by Edmonson et al. (1989). The mean ( \pm SD) BCS for all cows before the start of the experiment was $3.2 \pm 0.27$. Changes in BW and BCS were calculated as the difference between the value obtained at the end of the period and the value from the previous period. Individual intake of TMR was recorded daily throughout the trial by the roughage intake control feeders. The daily concentrate intake of each cow was recorded in the GreenFeed system (C-Lock Inc., Rapid City, SD) and included in total DMI. Silage, crimpled barley, rapeseed meal, and concentrate mixture were sampled at the end of each period and stored at $-20^{\circ} \mathrm{C}$ until further processing.

Milk yield was recorded with gravimetric milk recorders (SAC, S.A. Christensen and Co Ltd.). Milk samples were collected at 4 consecutive milkings from the afternoon of d 19 until the morning of d 21 in each period. The milk samples were preserved with bronopol and stored at $+8^{\circ} \mathrm{C}$ until analysis. Fecal grab samples were collected from the rectum of each cow once daily between d 19 and 21 in each period, pooled into 1 sample per cow and period, and then stored at $-20^{\circ} \mathrm{C}$ until further processing.

An open-circuit head chamber system (GreenFeed system) measured mass flux of $\mathrm{CH}_{4}, \mathrm{CO}_{2}$, and $\mathrm{O}_{2}$ automatically in the breath of each individual cow every time the cows visited the GreenFeed system (as described in detail by Huhtanen et al., 2015). The animals were trained to visit the GreenFeed station regularly before the experiment started. All animals visited the GreenFeed station several times per day during the whole experimental period, where they were offered concentrate every $5 \mathrm{~h}$. Concentrate was dispensed in up to 8 drops of $50 \mathrm{~g}$ each per visit to facilitate each visit lasting for around $8 \mathrm{~min}$. Gas production, recorded as a 3-d rolling average, generated during the last $7 \mathrm{~d}$ of each period was used in the statistical analysis. During the whole experiment, 5 recovery tests were made to calibrate the flux in the system, with mean recovery of $92.1 \%$, and calibration of each gas sensor was performed every second week using gases with known concentrations.

\section{Chemical Analysis and Calculations}

The feed analyses were performed by the laboratory at the Department of Animal Nutrition and Management at the Swedish University of Agricultural Science, Uppsala, Sweden. The DM content of the silage was determined by a 2-step procedure, first drying at $60^{\circ} \mathrm{C}$ overnight and milling and then drying at $60^{\circ} \mathrm{C}$ overnight according to Åkerlind et al. (2011). The DM content of the other TMR components and concentrate mixture was determined by drying at $103^{\circ} \mathrm{C}$ overnight

Table 1. Chemical composition (mean $\pm \mathrm{SD}$ ) of experimental feeds $(\mathrm{g} / \mathrm{kg}$ of DM unless otherwise stated)

\begin{tabular}{lccc}
\hline Item & Grass silage & Barley $^{1}$ & Rapeseed meal $^{2}$ \\
\hline $\mathrm{DM}, \mathrm{g} / \mathrm{kg}$ & $238 \pm 0.2$ & $632 \pm 18$ & $864 \pm 11$ \\
Ash & $65.4 \pm 1.1$ & $26.5 \pm 2.4$ & $77.4 \pm 0.9$ \\
$\mathrm{CP}$ & $155 \pm 3$ & $133 \pm 11$ & $332 \pm 4$ \\
Crude fat & $\mathrm{NA}^{3}$ & $25.1 \pm 0.4$ & $37.8^{4}$ \\
NDF & $444 \pm 11$ & $168 \pm 5$ & $334 \pm 4$ \\
Starch & $\mathrm{NA}$ & $530 \pm 21$ & 22.8 \\
Water-soluble carbohydrates & $2.0 \pm 1.4$ & $\mathrm{NA}$ & $\mathrm{NA}$ \\
Ruminal fluid-digestible OM & $87.5 \pm 1.0$ & $\mathrm{NA}$ & $\mathrm{NA}$ \\
VFA & $43.1 \pm 0.4$ & $\mathrm{NA}$ & $\mathrm{NA}$ \\
Ethanol & $5.6 \pm 1.0$ & $\mathrm{NA}$ & $\mathrm{NA}$ \\
pH & $3.72 \pm 0.01$ & $\mathrm{NA}$ & $\mathrm{NA}$ \\
$\mathrm{NE}, \mathrm{MJ} / \mathrm{kg}$ of DM & $6.19^{5}$ & $7.11^{5}$ & $6.61^{5}$ \\
$\mathrm{ME}, \mathrm{MJ} / \mathrm{kg}$ of DM & $11.3 \pm 0.1$ & $\mathrm{NA}$ & $\mathrm{NA}$ \\
\hline $\mathrm{Cr}$ & & &
\end{tabular}

${ }^{1}$ Crimped barley that was rolled, preserved with propionic acid, and stored airtight.

${ }^{2}$ Solvent-extracted and heat-moisture-treated rapeseed meal with low levels of glucosinolates and erucic acid (ExPro, AAK Sweden AB, Karlshamn, Sweden).

${ }^{3}$ Not analyzed.

${ }^{4}$ Where no SD is reported, pooled samples were analyzed. Where SD is reported, the number of samples used for analyses of chemical composition was 6 for silage and 3 for barley and rapeseed meal.

${ }^{5}$ Values from NorFor (2018). 
(European Union, 2009). Ash content for all feeds was determined by ignition at $550^{\circ} \mathrm{C}$ for $3 \mathrm{~h}$ (European Union, 2009). Acid-insoluble ash (AIA) content of all feeds was analyzed according to Van Keulen and Young (1977). Feeds were analyzed for CP in an automated Kjeldahl procedure (Foss, Hillerød, Denmark) and for ether extract according to European Commission regulations (European Union, 2009). The barley, rapeseed meal, and pelleted concentrate were analyzed enzymatically for starch (including maltodextrin) according to Larsson and Bengtsson (1983). All feeds were analyzed for NDF according to Chai and Udén (1998), and silage was analyzed for water-soluble carbohydrates according to Larsson and Bengtsson (1983). The silage samples were pressed and the silage juice was analyzed for $\mathrm{pH}, \mathrm{VFA}$, and ethanol. The VFA and ethanol were determined according to Ericson and André (2010). The silage samples were also analyzed for in vitro ruminal fluid-digestible OM according to Åkerlind et al. (2011). Net energy content in the feed and energy intake were estimated according to the NorFor system (Volden and Nielsen, 2011); values for maize starch were used because values for wheat starch were lacking. The ME content in the silage was calculated according to Lindgren (1979).

Milk samples were individually analyzed for composition of fat, fatty acids (FA), protein, lactose, and SCC using infrared Fourier-transform spectroscopy (CombiScope FTIR 300 HP, Delta Instruments B.V., Drachten, the Netherlands), and averages from the 4 milk samples for each period were used in the statistical analysis. The FA analyzed by spectroscopy were C14:0, C16:0, C18:0, and C18:1 cis-9. Lactose was corrected for lactase monohydrate by division by 1.053 . The ECM was calculated based on fat, protein, and lactose content according to Sjaunja et al. (1990). The feces were freeze dried, milled, and analyzed for DM, ash, and AIA. The total amount of feces was estimated from the total intake of AIA and the content of AIA in the feces (Van Keulen and Young, 1977). Total-tract apparent OM digestibility was calculated from estimated intake and excretion of $\mathrm{OM}$ from feed and feces as $\left(\mathrm{OM}_{\text {feed }}-\mathrm{OM}_{\text {feces }}\right) / \mathrm{OM}_{\text {feed }}$. The calculation was based on intake data from d 18 to 21 in each period. The $\mathrm{N}$ efficiency was calculated as (milk protein yield/6.38)/ (CP intake/6.25). Energy balance (EB) was calculated according to the NorFor system (Volden and Nielsen, 2011) as $\mathrm{NE}_{\text {intake }}-\left(\mathrm{NE}_{\mathrm{M}}+\mathrm{NE}_{\mathrm{L}}\right)$.

\section{Statistical Analyses}

All statistical analyses were performed with the MIXED procedure in SAS software (version 9.4, SAS Institute Inc., Cary, NC) using the model

$$
\begin{aligned}
Y_{i j k l} & =\mu+B_{i}+P_{j}+R_{k}+S_{1}+T_{m} \\
& +C_{n}\left(B_{i}\right)+T C_{m n}+\varepsilon_{i j k l m n},
\end{aligned}
$$

where $Y_{\mathrm{ijk}}$ is the dependent variable, $\mu$ is the overall mean, $B_{i}$ is the fixed effect of block $i, P_{j}$ is the fixed effect of period $j, R_{k}$ is the fixed effect of pretreatment $\mathrm{k}, \mathrm{S}_{1}$ is the fixed effect of treatment sequence $1, \mathrm{~T}_{\mathrm{m}}$ is the fixed effect of treatment $m, C_{n}\left(B_{i}\right)$ is the random effect of cow $\mathrm{n}$ within block $\mathrm{i}, \mathrm{TC}_{\mathrm{mn}}$ is the random treatment $\times$ cow interaction effect of treatment $m$ and cow $n$, and the $\varepsilon_{\mathrm{ijklmn}}$ is the random error. Interactions were calculated but removed from the final model if not significant. All residuals were tested for normality, and all but SCC and intake of starch followed a normal distribution. Therefore, those were log-transformed for the statistical analysis. Statistical significance was set at $P<0.05$, with tendencies noted at $P<0.10$.

\section{RESULTS AND DISCUSSION}

In the present study, enteric $\mathrm{CH}_{4}$ emissions were determined in dairy cows fed a grass silage-based diet supplemented with either glycerol or starch. Earlier studies investigating the effects of dietary glycerol on $\mathrm{CH}_{4}$ in cattle have been performed on beef steers either with a low level of glycerol inclusion (San Vito et al., 2016) or on a high-concentrate diet (Hales et al., 2015), which is not comparable with dairy cows fed a high level of glycerol and forage. For example, glycerol may decrease fiber digestibility (Donkin et al., 2009; Benedeti et al., 2018), which, in turn, would reduce DM digestibility. However, in the present study, DM digestibility was not reduced compared with starch supplementation. Additionally, others (Donkin et al., 2009; Kass et al., 2012) compared glycerol with fiber-containing feedstuff such as maize or barley, which makes interpretations of results more difficult because fiber can affect parameters such as DMI, rumen function, and digestibility.

Previous studies have shown no effect on DMI or FCM for dairy cows when feeding $150 \mathrm{~g} / \mathrm{kg}$ DM of glycerol (Donkin et al., 2009; Ezequiel et al., 2015), whereas feeding glycerol at $300 \mathrm{~g} / \mathrm{kg}$ of DM decreased DMI and FCM (Ezequiel et al., 2015). The glycerol dosage level is most likely of great importance for the outcome of the studies. Thus, in the present study we can only make conclusions regarding the dosage level of $200 \mathrm{~g} /$ $\mathrm{kg}$ of DM.

\section{DMI, Milk Yield, and Milk Composition}

Dry matter intake was $1.5 \mathrm{~kg} / \mathrm{d}$ higher with the GLY diet compared with the STA diet (Table 2). This corroborates findings by Kass et al. (2012), who replaced 
Table 2. Nutrient intake $(\mathrm{kg} / \mathrm{d})$, apparent digestibility of OM (OMD), and change in BCS and BW presented as LSM with SEM

\begin{tabular}{|c|c|c|c|c|}
\hline \multirow[b]{2}{*}{ Item } & \multicolumn{2}{|c|}{ Diet $^{1}$} & \multirow[b]{2}{*}{ SEM } & \multirow[b]{2}{*}{$P$-value } \\
\hline & Starch & Glycerol & & \\
\hline No. of observations ${ }^{2}$ & 33 & 33 & & \\
\hline DM & 20.1 & 21.6 & 0.46 & 0.01 \\
\hline $\mathrm{OM}$ & 18.3 & 19.7 & 0.42 & 0.01 \\
\hline $\mathrm{CP}$ & 2.82 & 3.02 & 0.065 & 0.02 \\
\hline NDF & 6.19 & 6.66 & 0.145 & 0.01 \\
\hline Ether extract & 0.65 & 0.70 & 0.015 & 0.01 \\
\hline Starch $\left(\log _{10}\right)$ & 0.66 & 0.07 & 0.009 & $<0.01$ \\
\hline Starch (antilog) & 4.60 & 1.18 & & \\
\hline Glycerol & 0.0 & 3.98 & 0.065 & $<0.01$ \\
\hline $\mathrm{NE}_{\mathrm{L}}, \mathrm{MJ} / \mathrm{d}$ & 129 & 135 & 3.0 & 0.10 \\
\hline Energy balance, ${ }^{3} \mathrm{MJ}$ of $\mathrm{NE}_{\mathrm{L}} / \mathrm{d}$ & 6.79 & 17.5 & 2.763 & 0.01 \\
\hline OMD, \% & 70.8 & 72.5 & 0.96 & 0.31 \\
\hline BCS change, ${ }^{4} \mathrm{BCS} / \mathrm{d}$ & -0.003 & -0.002 & 0.0049 & 0.87 \\
\hline BW change, $\mathrm{kg} / \mathrm{d}$ & 0.00 & -0.02 & 0.956 & 0.99 \\
\hline
\end{tabular}

${ }^{1}$ The 2 dietary treatments consisted of a TMR based on (g/kg of DM) grass silage (605), rapeseed meal (120), and barley (70) and either wheat starch or refined glycerol (200), fed ad libitum.

${ }^{2}$ Eleven cows were assigned to each of the 2 treatment sequences ABA and BAB in a switch-back, change-over design with 2 diets as treatments and 3 treatment periods.

${ }^{3}$ According to NorFor (2018; values for maize starch used instead of wheat starch).

${ }^{4} \mathrm{~A} 1$ - to 5-point system with 0.25-point intervals (Edmonson et al., 1989).

barley meal with up to $15 \%$ crude glycerol in the dairy cow diet. However, in that study, the NDF content was $11 \%$ higher in the barley meal diet than in the diet with $15 \%$ glycerol, which might have reduced DMI. The higher intake may also be caused by higher palatability of the sweet-tasting glycerol. We used refined glycerol (99.5\% purity) in the present study to avoid possible impurities such as salts and methanol present in crude glycerol (Thompson and He, 2006), which can reduce intake. In addition, the viscosity of glycerol may prevent segregation of different feed particles in a TMR (Drouillard, 2008), which could also explain the higher DMI values in cows fed the GLY diet. On the other hand, in the present study the added starch was a fine-grained powder, which can also have prevented segregation of feed particles when combined with the wet silage. Due to the higher DMI, intake of OM, CP, NDF, and ether extract was also higher for cows fed the GLY diet (Table 2). The cows consumed $4 \mathrm{~kg} / \mathrm{d}$ of glycerol (200 $\mathrm{g} / \mathrm{kg}$ of DM) in the GLY diet, which is a high inclusion rate compared with most other studies feeding glycerol to dairy cows. Despite higher DMI with the GLY diet, there was no treatment effect on energy intake due to a somewhat higher energy level estimated for starch than for glycerol (NorFor, 2018). It should be noted, however, that the net energy values used for both glycerol and starch were only rough estimates because sufficient data are lacking in the literature. Net energy value for maize starch was used because value for wheat starch was lacking. Wheat and maize starch are both considered fully digestible, but maize starch has lower rumen digestibility than wheat starch (Hindle et al., 2005). The maize starch that escapes rumen fermentation is mainly digested in the small intestine and absorbed as glucose with higher energetic efficiency (McLeod et al., 2006). Therefore, wheat starch might have a somewhat lower energy content than maize starch.

Despite the higher DMI in the present study, daily ECM yield was not improved by the GLY diet. However, the present study lacks power to identify treatment effects on yield below $2.3 \mathrm{~kg}$ of ECM. Feed efficiency, defined as ECM/NE $\mathrm{NE}_{\mathrm{L}}$, was reduced (Table 3). Similarly, Kass et al. (2012) found that mid-lactation cows responded with lower feed efficiency when barley was replaced with $15 \%$ glycerol. In the present study, the apparent OM digestibility did not differ between the 2 treatments. Thus, it is less likely that the lower feed efficiency was related to rumen digestibility. Our results are in line with those of Kass et al. (2012), who found no effect of glycerol inclusion on in sacco DM digestibility. As proposed by Donkin et al. (2009), glycerol might modulate postabsorptive lipid metabolism, which could partly explain the lower feed efficiency with dietary glycerol.

Nitrogen efficiency was decreased in the present study. To our knowledge, no other studies of feeding glycerol to dairy cows have reported $\mathrm{N}$ efficiency. When estimating $\mathrm{N}$ efficiency based on reported least squares means for milk protein yield and $\mathrm{CP}$ or $\mathrm{N}$ intake, some studies have shown a numerical increase (Donkin et al., 2009; Ezequiel et al., 2015), whereas others have shown a numerical decrease (Kass et al., 2012) with increasing 
Table 3. Effects of replacing starch with glycerol in the diet on milk performance, $\mathrm{N}$ efficiency, and feed conversion efficiency ${ }^{1}$

\begin{tabular}{|c|c|c|c|c|}
\hline \multirow[b]{2}{*}{ Item } & \multicolumn{2}{|c|}{ Diet } & \multirow[b]{2}{*}{ SEM } & \multirow[b]{2}{*}{$P$-value } \\
\hline & Starch & Glycerol & & \\
\hline No. of observations ${ }^{2}$ & 33 & 33 & & \\
\hline Milk yield, kg/d & 28.1 & 24.6 & 0.90 & 0.01 \\
\hline ECM yield, $\mathrm{kg} / \mathrm{d}$ & 29.7 & 28.4 & 0.94 & 0.27 \\
\hline Fat, $\mathrm{g} / \mathrm{kg}$ & 44.7 & 51.0 & 1.24 & $<0.01$ \\
\hline Protein, g/kg & 35.8 & 38.2 & 0.53 & $<0.01$ \\
\hline Lactose, $\mathrm{g} / \mathrm{kg}$ & 44.3 & 43.2 & 0.27 & $<0.01$ \\
\hline $\mathrm{C} 14: 0, \mathrm{~g} / 100 \mathrm{~g}$ of fat & 13.8 & 15.3 & 0.19 & $<0.01$ \\
\hline $\mathrm{C} 16: 0, \mathrm{~g} / 100 \mathrm{~g}$ of fat & 31.4 & 31.5 & 0.26 & 0.85 \\
\hline $\mathrm{C} 18: 0, \mathrm{~g} / 100 \mathrm{~g}$ of fat & 5.66 & 4.89 & 0.239 & 0.05 \\
\hline $\mathrm{C} 18: 1$ cis- $9, \mathrm{~g} / 100 \mathrm{~g}$ of fat & 17.1 & 15.2 & 0.32 & $<0.01$ \\
\hline $\mathrm{N}$ efficiency, ${ }^{3} \mathrm{~g} / \mathrm{kg}$ & 348 & 306 & 9.9 & $<0.01$ \\
\hline SCC $\left(\log _{10}\right)$ & 1.70 & 1.99 & 0.102 & 0.06 \\
\hline SCC antilog, cells/mL & 51,000 & 97,000 & - & - \\
\hline $\mathrm{ECM} / \mathrm{NE}_{\mathrm{L}}, \mathrm{kg} / \mathrm{MJ}$ & 0.23 & 0.21 & 0.006 & 0.03 \\
\hline
\end{tabular}

${ }^{1}$ Presented as LSM with SEM.

${ }^{2}$ Eleven cows were assigned to each of the 2 treatment sequences (ABA and $\mathrm{BAB}$ ) in a switch-back, change-over design with 2 diets as treatments and 3 treatment periods.

${ }^{3}$ Nitrogen efficiency $=($ milk protein yield $/ 6.38) /(\mathrm{CP}$ intake $/ 6.25)$.

dietary glycerol inclusion. Previous studies (Donkin et al., 2009; Rico et al., 2012) found no effect on rumen microbial CP production with dietary glycerol, why changes in $\mathrm{N}$ efficiency might result from postruminal or postabsorptive changes in $\mathrm{N}$ metabolism.

Milk yield was lower with the GLY diet, but milk fat and protein concentrations increased with glycerol inclusion in the present study (Table 3). Previous studies report conflicting responses in terms of fat and protein content in milk, with diets including up to $15 \%$ dietary glycerol showing no effect (Donkin et al., 2009) or an increase in protein content (Kass et al., 2012), whereas adding up to $18 \%$ of dietary glycerol increased both fat and protein contents in milk linearly (Gaillard et al., 2018). The conflicting results might depend on the inclusion level of dietary glycerol. It is possible that the higher milk fat and protein concentrations in the present study were related to increased butyrate production (Huhtanen et al., 1993), when glycerol was fermented in the rumen as has been reported by others (Rémond et al., 1993; Ariko et al., 2015; Castagnino et al., 2018). It is reasonable to assume that the higher starch intake among STA cows contributed to the reduced fat content in milk from those cows. It is generally accepted that high-starch diets reduce milk fat content, whereas the effect on protein content is less clear (Sutton, 1989).

The most prevalent milk FA are presented in Table 3. The FA C14:0 in milk originates from mammary de novo synthesis of FA (Palmquist et al., 1969). The present results thus indicate that the GLY diet stimulated mammary de novo synthesis of milk fat. On the other hand, the milk concentrations of $\mathrm{C} 18: 1$ cis-9 and C18:0 were lower or tended to be lower among cows fed the same diet. These are preformed FA that are released from the adipose tissue during negative EB (Rukkwamsuk et al., 2000). Taken together, these results indicate that cows fed the GLY diet favored mammary de novo synthesis and reduced adipose tissue lipolysis. Similar studies examining milk FA profiles in connection with feeding glycerol to dairy cows have also found decreases in the concentration of C18:1 cis-9 (Ariko et al., 2015; Gaillard et al., 2018). It is possible that the decrease in $\mathrm{C} 18: 0$ and $\mathrm{C} 18: 1$ cis-9 FA in milk fat reflects reduced net mobilization of body fat reserves (Gross et al., 2011). This would agree with the observation that cows fed the GLY diet were in a more positive EB (Table 2 ). However, BW change and BCS change were not affected by treatment (Table 2). The difference in EB, about $10 \mathrm{MJ} / \mathrm{d}$, might have been too limited to create a significant effect with treatment periods of 3 wk. Kass et al. (2012) also did not find any effect on BW change with up to $15 \%$ glycerol inclusion to mid-lactation dairy cows but found decreasing plasma nonesterified FA concentrations with increasing glycerol inclusion, supporting the suggestion that glycerol reduces lipid mobilization. It is possible that the ME of glycerol was also slightly overestimated in the present study because the estimated energy losses as $\mathrm{CH}_{4}$ were about $3 \mathrm{MJ} / \mathrm{d}$ higher on the GLY diet (Table 2).

\section{Gas Emissions}

There was no significant difference between the GLY and STA diets for $\mathrm{CH}_{4} / \mathrm{DMI}$ in the present study (Table 
Table 4. Methane $\left(\mathrm{CH}_{4}\right), \mathrm{CO}_{2}$, and $\mathrm{O}_{2}$ in exhalent and exhaled air and relationships among $\mathrm{CH}_{4}$, feed intake, and lactation performance ${ }^{1}$

\begin{tabular}{|c|c|c|c|c|}
\hline \multirow[b]{2}{*}{ Item } & \multicolumn{2}{|c|}{ Diet } & \multirow[b]{2}{*}{ SEM } & \multirow[b]{2}{*}{$P$-value } \\
\hline & Starch & Glycerol & & \\
\hline No. of observations ${ }^{2}$ & 33 & 33 & & \\
\hline $\mathrm{CH}_{4}, \mathrm{~g} / \mathrm{d}$ & 423 & 482 & 12.4 & $<0.01$ \\
\hline $\mathrm{CO}_{2}, \mathrm{~g} / \mathrm{d}$ & 12,200 & 12,500 & 246.4 & 0.12 \\
\hline $\mathrm{O}_{2}, \mathrm{~g} / \mathrm{d}$ & 8,400 & 8,800 & 167.9 & 0.01 \\
\hline $\mathrm{CH}_{4} / \mathrm{DMI}, \mathrm{g} / \mathrm{kg}$ of DM & 21.3 & 22.4 & 0.79 & 0.17 \\
\hline $\mathrm{CH}_{4} / \mathrm{ECM}, \mathrm{g} / \mathrm{kg}$ & 14.7 & 17.1 & 0.78 & $<0.01$ \\
\hline $\mathrm{CO}_{2} / \mathrm{DMI}, \mathrm{g} / \mathrm{kg}$ of $\mathrm{DM}$ & 610 & 580 & 17.6 & 0.10 \\
\hline $\mathrm{CO}_{2} / \mathrm{ECM}, \mathrm{g} / \mathrm{kg}$ & 420 & 440 & 20.3 & 0.18 \\
\hline $\mathrm{RQ}^{3^{\prime}}$ & 1.04 & 1.02 & 0.006 & 0.10 \\
\hline
\end{tabular}

${ }^{1}$ Presented as LSM with SEM.

${ }^{2}$ Eleven cows were assigned to each of the 2 treatment sequences (ABA and BAB) in a switch-back, change-over design with 2 diets as treatments and 3 treatment periods.

${ }^{3}$ Respiratory quotient $(\mathrm{RQ})=\mathrm{CO}_{2} / \mathrm{O}_{2}$.

4). Our initial assumption was that glycerol would be rapidly absorbed across the rumen epithelium and that the rumen microbes would have a limited amount of glycerol to ferment and thereby reduce $\mathrm{CH}_{4}$ production, as indicated by findings by Werner Omazic et al. (2015). However, we found that glycerol inclusion increased $\mathrm{CH}_{4}$ production compared with cows given the STA diet, indicating that most of the glycerol consumed was metabolized in the rumen (Table 4). Dietary glycerol did not reduce $\mathrm{CH}_{4}$ in the present study, which may be explained by the glycerol being mixed into the TMR. This can affect its fate when entering the rumen, by making glycerol less available for absorption. Linke et al. (2004) found that when dairy cows were orally drenched with $1 \mathrm{~kg} / \mathrm{d}$ of glycerol, blood plasma concentrations of both glucose and insulin increased, whereas no effect was found when glycerol was mixed with the feed. These results indicate that when glycerol is mixed with the feed, the glycerol is fermented in the rumen to a greater extent than suggested by Werner Omazic et al. (2015).

Another explanation for the lack of effect of the GLY diet to lower $\mathrm{CH}_{4}$ emissions could be altered VFA production patterns and methanogenesis. Formation of acetate from carbohydrates is the main hydrogen source in the rumen, although butyrate formation also generates hydrogen, but less than acetate (Van Soest, 1994). The hydrogen needs to be disposed of, and the main way of eliminating it is by methanogens that use hydrogen to reduce $\mathrm{CO}_{2}$ to $\mathrm{CH}_{4}$, but formation of propionate from pyruvate is also a hydrogen-using reaction (Moss et al., 2000). Glycerol administration of 100 to $150 \mathrm{~g} / \mathrm{kg}$ of DM in cattle diets replacing feeds such as maize silage, maize, and barley decreases the proportion of acetate, whereas the proportions of propionate and butyrate increase (Rémond et al., 1993; Ariko et al., 2015; Castagnino et al., 2018). Wheat starch is rapidly degradable (Reynolds, 2006), and at least $90 \%$ is fermented in the rumen to VFA, which in turn are absorbed through the rumen epithelium (Ørskov, 1986). It is thus reasonable to assume that for the cows in the present study, virtually all wheat starch consumed was fermented and absorbed from the gastrointestinal tract as VFA. Starch fermentation is known to generally increase propionate production (Sutton et al., 2003; Agle et al., 2010). Avila-Stagno et al. (2014) found in an in vitro study that glycerol increased $\mathrm{CH}_{4}$ production even though propionate and butyrate production increased. Those authors suggested that this is because propionate produces hydrogen according to stoichiometric calculations when glycerol, instead of carbohydrates, is fermented to propionate. Glycerol $\left(\mathrm{C}_{3} \mathrm{H}_{8} \mathrm{O}_{3}\right)$ enters the glycolysis pathway as D-glyceraldehyde 3-P along with production of $\mathrm{NADH}+\mathrm{H}^{+}$(Avila-Stagno et al., 2014; Benedeti et al., 2018). When, on the other hand, glucose from starch enters the glycolysis pathway as D-glyceraldehyde $3-\mathrm{P}$, no $\mathrm{NADH}+\mathrm{H}^{+}$is produced. Reoxidation of NADH produces $\mathrm{H}_{2}$ that can be used for reducing $\mathrm{CO}_{2}$ to $\mathrm{CH}_{4}$ by methanogens.

\section{CONCLUSIONS}

In this study on 22 Swedish Red dairy cows in mid lactation, replacing wheat starch $(200 \mathrm{~g} / \mathrm{kg}$ of DM) with refined glycerol in a grass silage and barley-based TMR increased $\mathrm{CH}_{4}$ emissions and DMI, with no effect on $\mathrm{CH}_{4} / \mathrm{DMI}$ or ECM yield. Our results suggest that the energy value of glycerol was overestimated relative to that of wheat starch. This was not an effect of reduced $\mathrm{OM}$ digestibility. Energy losses with $\mathrm{CH}_{4}$ might have contributed to the lower-than-expected energy contribution of glycerol. Furthermore, dietary glycerol 
might have reduced adipose lipolysis, which could be mistaken for a reduced energy contribution.

\section{ACKNOWLEDGMENTS}

This research was funded by the research program AquaAgri, which is jointly funded by Formas (Stockholm, Sweden), Mistra (Stockholm, Sweden), and Lantmännen Research Foundation (Stockholm, Sweden). The authors sincerely thank the staff at the Röbäcksdalen research farm in Umeå, Sweden, and the staff at the laboratory of the Department of Animal Nutrition and Management in Uppsala, Sweden, for their help during the experiment. The postdoctoral research fellowship of Marko Kass at the Swedish University of Agricultural Sciences was supported by the Visby Programme of the Swedish Institute (Stockholm, Sweden).

\section{REFERENCES}

Agle, M., A. N. Hristov, S. Zaman, C. Schneider, P. M. Ndegwa, and V. K. Vaddella. 2010. Effect of dietary concentrate on rumen fermentation, digestibility, and nitrogen losses in dairy cows. J. Dairy Sci. 93:4211-4222. https://doi.org/10.3168/jds.2009-2977.

Åkerlind, M., M. Weisbjerg, T. Eriksson, P. Udén, B. L. Ólafsson, O. Harstad, and H. Volden. 2011. Feed analyses and digestion methods. Pages 41-54 in NorFor-The Nordic Feed Evaluation System. Vol. 130. H. Volden, ed. Wageningen Academic Publishers, Wageningen, the Netherlands.

Ariko, T., M. Kass, M. Henno, V. Fievez, O. Kärt, T. Kaart, and M. Ots. 2015. The effect of replacing barley with glycerol in the diet of dairy cows on rumen parameters and milk fatty acid profile. Anim. Feed Sci. Technol. 209:69-78. https://doi.org/10.1016/j.anifeedsci 2015.08.004.

Avila, J. S., A. V. Chaves, M. Hernandez-Calva, K. A. Beauchemin, S. M. McGinn, Y. Wang, O. M. Harstad, and T. A. McAllister. 2011. Effects of replacing barley grain in feedlot diets with increasing levels of glycerol on in vitro fermentation and methane production. Anim. Feed Sci. Technol. 166-167:265-268. https://doi.org/ 10.1016/j.anifeedsci.2011.04.016.

Avila-Stagno, J., A. V. Chaves, G. O. Ribeiro Jr., E. M. Ungerfeld, and T. A. McAllister. 2014. Inclusion of glycerol in forage diets increases methane production in a rumen simulation technique system. Br. J. Nutr. 111:829-835. https://doi.org/10.1017/ S0007114513003206.

Benedeti, P. D. B., M. A. Fonseca, T. Shenkoru, M. I. Marcondes, E. M. de Paula, L. G. da Silva, and A. P. Faciola. 2018. Does partial replacement of corn with glycerine in beef cattle diets affect in vitro ruminal fermentation, gas production kinetic, and enteric greenhouse gas emissions? PLoS One 13:e0199577. https://doi .org/10.1371/journal.pone.0199577.

Boyd, J., J. W. West, and J. K. Bernard. 2011. Effects of the addition of direct-fed microbials and glycerol to the diet of lactating dairy cows on milk yield and apparent efficiency of yield. J. Dairy Sci. 94:4616-4622. https://doi.org/10.3168/jds.2010-3984.

Castagnino, P. S., E. E. Dallantonia, G. Fiorentini, E. San Vito, J. D. Messana, L. O. Lima, T. A. Simioni, and T. T. Berchielli. 2018. Changes in ruminal fermentation and microbial population of feedlot Nellore cattle fed crude glycerin and virginiamycin. Anim. Feed Sci. Technol. 242:69-76. https://doi.org/10.1016/j.anifeedsci.2018 .05.007.

Castagnino, P. S., J. D. Messana, G. Fiorentini, R. B. de Jesus, E. San Vito, I. P. C. Carvalho, and T. T. Berchielli. 2015. Glycerol combined with oils did not limit biohydrogenation of unsaturated fatty acid but reduced methane production in vitro. Anim. Feed Sci. Technol. 201:14-24. https://doi.org/10.1016/j.anifeedsci.2014 .12 .004 .

Chai, W. H., and P. Udén. 1998. An alternative oven method combined with different detergent strengths in the analysis of neutral detergent fibre. Anim. Feed Sci. Technol. 74:281-288. https://doi .org/10.1016/S0377-8401(98)00187-4.

Danielsson, R., A. Werner-Omazic, M. Ramin, A. Schnürer, M. Griinari, J. Dicksved, and J. Bertilsson. 2014. Effects on enteric methane production and bacterial and archaeal communities by the addition of cashew nut shell extract or glycerol - An in vitro evaluation. J. Dairy Sci. 97:5729-5741. https://doi.org/10.3168/ jds.2014-7929.

Donkin, S. S. 2008. Glycerol from biodiesel production: The new corn for dairy cattle. Rev. Bras. Zootec. 37:280-286. https://doi.org/10 $.1590 /$ S1516-35982008001300032.

Donkin, S. S., S. L. Koser, H. M. White, P. H. Doane, and M. J. Cecava. 2009. Feeding value of glycerol as a replacement for corn grain in rations fed to lactating dairy cows. J. Dairy Sci. 92:5111-5119. https://doi.org/10.3168/jds.2009-2201.

Drouillard, J. S. 2008. Glycerin as a feed for ruminants: Using glycerin in high-concentrate diets. J. Anim. Sci. 86(E-Suppl. 2):392.

European Union. 2009. Commission Regulation (EC) No 152/2009 of 27 January 2009 laying down the methods of sampling and analysis for the official control of feed. Off. J. L 54:1-130.

Edmonson, A. J., I. J. Lean, L. D. Weaver, T. Farver, and G. Webster. 1989. A body condition scoring chart for Holstein dairy cows. J. Dairy Sci. 89:68-78. https://doi.org/10.3168/jds.S0022 -0302(89)79081-0.

Ericson, B., and J. André. 2010. HPLC-Applications for agricultural and animal science. Pages 23-26 in Proc. 1st Nordic Feed Science Conference, Uppsala, Sweden. The Swedish University of Agricultural Science, Uppsala, Sweden.

Ezequiel, J. M. B., J. B. D. Sancanari, O. R. Machado Neto, Z. F. da Silva, M. T. C. Almeida, D. A. V. Silva, F. O. S. van Cleef, and E. H. C. B. van Cleef. 2015. Effects of high concentrations of dietary crude glycerin on dairy cow productivity and milk quality. J. Dairy Sci. 98:8009-8017. https://doi.org/10.3168/jds.2015-9448.

Gaillard, C., M. T. Sørensen, M. Vestergaard, M. R. Weisbjerg, M. K. Larsen, H. Martinussen, U. Kidmose, and J. Sehested. 2018 Effect of substituting barley with glycerol as energy feed on feed intake, milk production and milk quality in dairy cows in mid or late lactation. Livest. Sci. 209:25-31. https://doi.org/10.1016/ j.livsci.2018.01.006.

Gross, J., H. A. van Dorland, R. M. Bruckmaier, and F. J. Schwarz. 2011. Milk fatty acid profile related to energy balance in dairy cows. J. Dairy Res. 78:479-488. https://doi.org/10.1017/ S0022029911000550.

Hales, K. E., A. P. Foote, T. M. Brown-Brandl, and H. C. Freetly. 2015. Effects of dietary glycerin inclusion at $0,5,10$, and 15 percent of dry matter on energy metabolism and nutrient balance in finishing beef steers. J. Anim. Sci. 93:348-356. https://doi.org/10 $.2527 /$ jas.2014-8075.

Hindle, V. A., A. M. van Vuuren, A. Klop, A. A. Mathijssen-Kamman, A. H. van Gelder, and J. W. Cone. 2005. Site and extent of starch degradation in the dairy cow-A comparison between in vivo, in situ and in vitro measurements. J. Anim. Physiol. Anim. Nutr. (Berl.) 89:158-165. https://doi.org/10.1111/j.1439-0396.2005 $.00560 . x$.

Hristov, A. N., J. Oh, J. L. Firkins, J. Dijkstra, E. Kebreab, G. Waghorn, H. P. S. Makkar, A. T. Adesogan, W. Yang, C. Lee, P. J. Greber, B. Henderson, and J. M. Tricarico. 2013. Mitigation of methane and nitrous oxide emissions from animal operations: I. A review of enteric methane mitigation options. J. Anim. Sci. 91:5045-5069. https://doi.org/10.2527/jas.2013-6583.

Huhtanen, P., E. H. Cabezas-Garcia, S. Utsumi, and S. Zimmerman. 2015. Comparison of methods to determine methane emissions from dairy cows in farm conditions. J. Dairy Sci. 98:3394-3409. https://doi.org/10.3168/jds.2014-9118.

Huhtanen, P., H. Miettinen, and M. Ylinen. 1993. Effect of increasing ruminal butyrate on milk yield and blood constituents in dairy 
cows fed a grass silage-based diet. J. Dairy Sci. 76:1114-1124. https://doi.org/10.3168/jds.S0022-0302(93)77440-8.

Kass, M., T. Ariko, T. Kaart, E. Rihma, M. Ots, D. Arney, and O. Kärt. 2012. Effect of replacement of barley meal with crude glycerol on lactation performance of primiparous dairy cows fed a grass silage-based diet. Livest. Sci. 150:240-247. https://doi.org/ 10.1016/j.livsci.2012.09.007.

Larsson, K., and S. Bengtsson. 1983. Determination of Non-Structural Carbohydrates in Plant Material [in Swedish]. National Laboratory for Agricultural Chemistry, Uppsala, Sweden.

Lee, S. Y., S. M. Lee, Y. B. Cho, D. K. Kam, S. C. Lee, C. H. Kim, and S. Seo. 2011. Glycerol as a feed supplement for ruminants: In vitro fermentation characteristics and methane production. Anim. Feed Sci. Technol. 166-167:269-274. https://doi.org/10.1016/j .anifeedsci.2011.04.070.

Lindgren, E. 1979. The Nutritional Value of Roughages Determined In Vivo and by Laboratory Methods [in Swedish]. The Swedish University of Agricultural Science, Uppsala, Sweden.

Linke, P., J. M. DeFrain, A. R. Hippen, and P. W. Jardon. 2004. Ruminal and plasma responses in dairy cows to drenching or feeding glycerol. J. Dairy Sci. 87(Suppl. 1):343 (Abstr.)

McAllister, T. A., K. A. Beauchemin, S. M. McGinn, X. Hao, and P. H. Robinson. 2011. Preface: Greenhouse gases in animal agriculture - Finding a balance between food production and emissions. Anim. Feed Sci. Technol. 166-167:1-6. https://doi.org/10.1016/j .anifeedsci.2011.04.057.

McLeod, K. R., R. L. Baldwin VI, S. W. El-Kadi, and D. L. Harmon. 2006. Site of starch digestion: Impact on energetic efficiency and glucose metabolism in beef and dairy cattle. Pages 129-136 in Cattle Grain Processing Symposium, Tulsa, OK. Oklahoma State University, Stillwater.

Moss, A. R., J. P. Jouany, and J. Newbold. 2000. Methane production by ruminants: Its contribution to global warming. Ann. Zootech. 49:231-253. https://doi.org/10.1051/animres:2000119.

NorFor. 2018. NorFor feedtable. Retrieved May 24, 2018. http://www .norfor.info/feed-table/.

Ørskov, E. R. 1986. Starch digestion and utilization in ruminants. J. Anim. Sci. 63:1624-1633. https://doi.org/10.2527/jas1986 $6351624 x$.

Palmquist, D. L., C. L. Davis, R. E. Brown, and D. S. Sachan. 1969. Availability and metabolism of various substrates in ruminants. V. Entry rate into the body and incorporation into milk fat of $\mathrm{d}(-)$ $\beta$-hydroxybutyrate. J. Dairy Sci. 52:633-638. https://doi.org/10 .3168/jds.S0022-0302(69)86620-8.

Ramin, M., and P. Huhtanen. 2013. Development of equations for predicting methane emissions from ruminants. J. Dairy Sci. 96:24762493. https://doi.org/10.3168/jds.2012-6095.

Rémond, B., E. Souday, and J. P. Jouany. 1993. In vitro and in vivo fermentation of glycerol by rumen microbes. Anim. Feed Sci. Technol. 41:121-132. https://doi.org/10.1016/0377-8401(93)90118-4.

Reynolds, C. K. 2006. Production and metabolic effects of site of starch digestion in dairy cattle. Anim. Feed Sci. Technol. 130:7894. https://doi.org/10.1016/j.anifeedsci.2006.01.019.
Rico, D. E., Y. H. Chung, C. M. Martinez, T. W. Cassidy, K. S. Heyler, and G. A. Varga. 2012. Effects of partially replacing dietary starch with dry glycerol in a lactating cow diet on ruminal fermentation during continuous culture. J. Dairy Sci. 95:3310-3317. https://doi.org/10.3168/jds.2011-5059.

Rukkwamsuk, T., M. J. H. Geelen, T. A. M. Kruip, and T. Wensing. 2000. Interrelation of fatty acid composition in adipose tissue, serum, and liver of dairy cows during the development of fatty liver postpartum. J. Dairy Sci. 83:52-59. https://doi.org/10.3168/jds .S0022-0302(00)74854-5.

Russell, J. B. 1998. The importance of $\mathrm{pH}$ in the regulation of ruminal acetate to propionate ratio and methane production in vitro. J. Dairy Sci. 81:3222-3230. https://doi.org/10.3168/jds.S0022 -0302(98)75886-2.

San Vito, E., J. F. Lage, J. D. Messana, E. E. Dallantonia, R. T. S. Frighetto, R. A. Reis, A. J. Neto, and T. T. Berchielli. 2016. Performance and methane emissions of grazing Nellore bulls supplemented with crude glycerine. J. Anim. Sci. 94:4728-4737. https:// doi.org/10.2527/jas.2016-0530.

Sjaunja, L. O., L. Baevre, L. Junkkarinen, J. Pedersen, and J. Setälä. 1990. A Nordic proposal for an energy corrected milk (ECM) formula. Pages 156-192 in Performance Recording of Animals: 27th Biennial Session of the International Committee of Animal Recording, Paris, France. Center for Agricultural Publishing and Documentation, Wageningen, the Netherlands.

Sutton, J. D. 1989. Altering milk composition by feeding. J. Dairy Sci. 72:2801-2814. https://doi.org/10.3168/jds.S0022-0302(89)79426 -1 .

Sutton, J. D., M. S. Dhanoa, S. V. Morant, J. France, D. J. Napper, and E. Schuller. 2003. Rates of production of acetate, propionate, and butyrate in the rumen of lactating dairy cows given normal and low-roughage diets. J. Dairy Sci. 86:3620-3633. https://doi .org/10.3168/jds.S0022-0302(03)73968-X.

Thompson, J. C., and B. B. He. 2006. Characterization of crude glycerol from biodiesel production from multiple feedstocks. Appl. Eng. Agric. 22:261-265. https://doi.org/10.13031/2013.20272.

US EPA (United States Environmental Protection Agency). 2013. Global Mitigation of Non- $\mathrm{CO}_{2}$ Greenhouse Gases: 2010-2030. EPA-430-R-13-011. US EPA, Washington, DC.

Van Keulen, J., and B. A. Young. 1977. Evaluation of acid-insoluble ash as a natural marker in ruminant digestibility studies. J. Anim. Sci. 44:282-287. https://doi.org/10.2527/jas1977.442282x.

Van Soest, P. J. 1994. Nutritional Ecology of the Ruminant. Cornell University Press, Ithaca, NY.

Volden, H., and N. I. Nielsen. 2011. Energy and metabolizable protein supply. Pages 81-84 in NorFor - The Nordic Feed Evaluation System. Vol. 130. H. Volden, ed. Wageningen Academic Publishers, Wageningen, the Netherlands.

Werner Omazic, A., C. Kronqvist, L. Zhongyan, H. Martens, and K. Holtenius. 2015. The fate of glycerol entering the rumen of dairy cows and sheep. J. Anim. Physiol. Anim. Nutr. (Berl.) 99:258-264. https://doi.org/10.1111/jpn.12245. 